\title{
Tremor in neuropathies of different origin
}

\section{Drżenie w polineuropatiach o różnej etiologii}

\author{
Anna Wasielewska', Monika Rudzińska', Tomasz Tomaszewski', Krzysztof Banaszkiewizz', Magdalena Wójcik-Pędziwiatrr', \\ Małgorzata Dec-Ćwiek', Anna Zajączkowska', Andrzej lzworski', Andrzej Szczudlik'
}

1 Department of Neurology, Jagiellonian University Medical College, Krakow, Poland

2Department of Automatics, University of Science and Technology, Krakow, Poland

Neurologia i Neurochirurgia Polska 2013; 47, 6: 525-533

Dol: 10.51 14/ninp.2013.34695

\section{Streszczenie}

Wstęp i cel pracy: Drżenie towarzyszy niektórym neuropatiom obwodowym, ale jego rozpowszechnienie i charakterystyka jest słabo poznana. Celem pracy było określenie częstości występowania i charakterystyki drżenia kończyn górnych w polineuropatiach o różnej etiologii oraz zbadanie zależności między występowaniem drżenia a klinicznymi i elektrofizjologicznymi cechami polineuropatii.

Materiał i metody: Do badania zakwalifikowano 89 chorych z rozpoznaniem polineuropatii o określonej etiologii i 50-osobową grupę kontrolną dobraną pod względem płci i wieku. Zebrano szczegółowy wywiad dotyczący drżenia kończyn górnych oraz wykonano kliniczną i aparaturową ocenę drżenia za pomocą akcelerometru trójosiowego i elektromiografii. Na podstawie testu obciążenia wyróżniono drżenie typu drżenia samoistnego lub o charakterze nasilonego drżenia fizjologicznego.

Wyniki: U chorych z polineuropatią występowanie drżenia, zarówno w ocenie klinicznej (59,5\%), jak i aparaturowej (74\%), stwierdzono znamiennie częściej niż w grupie kontrolnej (12\%). Obecność drżenia obserwowano we wszystkich badanych neuropatiach, z wyjątkiem polineuropatii z paraproteinemią $\operatorname{IgM}$. Drżenie towarzyszące polineuropatii, niezależnie od jej etiologii, było najczęściej posturalne (70\%), rzadziej spoczynkowe $(51 \%)$ lub kinetyczne (32\%), i miało niewielkie nasilenie. We wszystkich polineuropatiach dominowało drżenie typu drżenia samoistnego. Występowanie drżenia nie zależało ani od dominacji uszkodzenia aksonalnego lub demielinizacyjnego, ani od

Correspondence address: Anna Wasielewska, MD, Department of Neurology, Jagiellonian University Medical College, 3 Botaniczna St., Krakow 31-503, Poland,e-mail: anna.wasielewska@tlen.pl

Received: 2.10.2012; accepted: 13.03.2013 
tion velocity or other electrophysiological findings of the investigated upper limb nerves.

Conclusion: Tremor accompanies $60-70 \%$ of patients with polyneuropathy; it is mostly postural, ET-L type with mild severity, and unrelated to other typical clinical and electrophysiological findings of neuropathy.

Key words: neuropathy, polyneuropathy, tremor, essential tremor.

\section{Introduction}

Tremor is defined as oscillatory, rhythmic and involuntary movement of a body part caused by alternating or simultaneous contractions of agonistic and antagonistic muscles. It is mostly observed in upper and lower limbs, rarely in the head, trunk or tongue. Tremor results from the activity of tremor generators located peripherally or centrally in the medulla or brain. Slight, invisible to the naked eye physiological tremor can be registered in healthy people using special equipment, such as an accelerometer. Affected by emotions, stimulating agents or many other factors, physiological tremor can intensify and become more apparent - so-called enhanced physiological tremor (EPT). The most common pathological cause of tremor is essential tremor (ET), present in approximately $5 \%$ of the general population $[1,2]$

Tremor is the main or accompanying symptom in many diseases of the central and peripheral nervous system. Tremor accompanies some peripheral neuropathies, but the prevalence and characteristics of tremor in these diseases are not well known. It is observed usually in distal parts of upper limbs as postural and kinetic, very rarely as resting tremor [3-5]. As yet, concomitant tremor has been described in detail only in inflammatory and hereditary polyneuropathies [1,2,5-7].

The aim of this study was to assess the prevalence and the characteristics of tremor of upper limbs in different types of neuropathy, as well as relations between tremor characteristics and the results of nerve conduction studies.

\section{Material and methods}

Recruitment of patients for the study was based on a review of an electronic database of patients admitted to the Neurology Clinic, University Hospital in Krakow between 2008 and 2010 for the differential diagnosis of clinically presented neuropathy. Patients with diabetic zwolnienia szybkości przewodzenia czy innych parametrów oceny elektrofizjologicznej nerwów obwodowych kończyn górnych. Wniosek: Drżenie kończyn górnych występuje u 60-70\% chorych z polineuropatiami o różnej etiologii, jest najczęściej posturalne, typu drżenia samoistnego, ma niewielkie nasilenie i nie zależy od rodzaju polineuropatii ani od zwolnienia szybkości przewodzenia w nerwach.

Słowa kluczowe: neuropatia, polineuropatia, drżenie, drżenie samoistne

neuropathy were also recruited from the Clinic of Metabolic Diseases, University Hospital in Krakow. Only patients with a diagnosis of distal symmetrical sensorymotor diabetic polyneuropathy (DP), monoclonal IgM polyneuropathy (PIgM), polyneuropathy in chronic alcoholism (alcoholic polyneuropathy - AP), genetically confirmed neuropathy (Charcot-Marie-Tooth type 1 - CMT1) and chronic inflammatory demyelinating polyradiculoneuropathy (CIDP) were included in the study.

Exclusion criteria for the study were: the coexistence of pathologies that can cause polyneuropathy, the presence of focal lesions in brain neuroimaging, and the coexistence of diseases of the nervous system and of the internal organs that in the clinical picture may present tremors (e.g., Parkinson disease and other parkinsonian syndromes, essential tremor, Wilson disease, hyperthyroidism, liver failure). Patients receiving medication which can potentially trigger tremor such as neuroleptics, metoclopramide, amiodarone and others, abusers of alcohol (except for alcoholic polyneuropathy) and those exposed to toxic agents (mercury, lead) were also excluded from the study.

Polyneuropathy was diagnosed based on clinical and electrophysiological assessment using nerve conduction tests and criteria suggested by Tankisi $e t$ al. [8]. The diagnosis of CMT1, in addition to clinical and electrophysiological features of demyelinating polyneuropathy, was based on genetic investigation evidenced mutation in the PMP-22 gene (Laboratory of Molecular Biology and Genetic Diagnosis, Department of Clinical Biochemistry, Jagiellonian University Medical College). Chronic inflammatory demyelinating polyradiculoneuropathy was diagnosed in cases of progressive - for at least two months - demyelinating polyneuropathy with elevated levels of protein in the cerebrospinal fluid, after excluding other possible causes such as cancer, hormonal disorders, metabolic disorders (porphyria, diabetes mellitus, uraemia), nutritional deficiencies, intoxication with 
heavy metals, drugs, infections (Lyme disease) and immune disorders [9-11]. Monoclonal IgM polyneuropathy was diagnosed in patients with polyneuropathy and elevated titres of IgM antibodies in the immunoelectrophoresis of serum proteins, and not confirmed by biopsy $[12,13]$. Diabetic polyneuropathy was diagnosed in patients with diabetes mellitus after exclusion of other possible causes of polyneuropathy. Alcoholic polyneuropathy was diagnosed in chronic alcohol abusers with laboratory findings of liver damage.

Persons of both sexes aged from 31 to 82 years, recruited from life partners or patients' visitors genetically unrelated to them, without the presence of neurological disease in the history or neurological examination, gave their informed consent to participate in the study, thereby qualifying for the control group.

A detailed interview of each patient was performed, concerning symptoms and the course of polyneuropathy as well as presence, intensity, circumstances of onset and duration of tremor, the presence of potential tremor triggering factors such as taking tremorogenic medications and stimulants (coffee, alcohol, tobacco), presence of hormonal disturbances or others. Each patient had a neurological and electrophysiological examination including motor and sensory conduction velocity tests in upper and lower limbs. The neuropathy type (axonal, demyelinating, mixed) was defined according to published criteria [8].

The presence of resting, postural and kinetic tremor was determined for each patient as well as for the control group, by direct observation (clinical assessment) and through the simultaneous registration of tremors by triaxial accelerometry and superficial EMG recording. Clinical and instrumental assessments were performed in three positions: with the upper limbs supported (resting tremor), with the upper limbs outstretched (postural tremor), and during the finger-nose test and the Archimedes spiral drawing test (kinetic tremor). The examination of tremor was performed in the morning, after 30 minutes of rest, and at least 2 hours after patients had drunk tea or coffee or had smoked.

For assessment of tremor in the upper limbs, the triaxial accelerometer (TSD 109, BIOPACK System Inc., US) was attached by Velcro strips to the proximal phalanx of the middle finger. In the accelerometric assessment, tremor was identified on the basis of a characteristic peak of dominant frequency in the tremor spectrum. This method was used to assess the frequency and severity of tremor. Movement acceleration measured in successive time periods is an output signal from the ac- celerometer. The next step is to calculate the frequency domain representation (discrete Fourier transform) of that signal for the range from $2 \mathrm{~Hz}$ to $16 \mathrm{~Hz}$. The tremor intensification coefficient for acceleration $W_{s}$ was defined as follows:

$$
W_{s}=\frac{\max \left(f f \_s(1: 20)\right)}{\operatorname{mean}(f f] s(1: 20))}
$$

where:

mean is a function calculating the arithmetic average of the data vector,

$f f t s$ is the Fourier transform of the acceleration in the frequency range from $1 \mathrm{~Hz}$ to $20 \mathrm{~Hz}$.

Tremor amplitude was calculated from the power spectral density of the spectrogram of the peak of the dominant frequency. The introduced coefficient $W$ shows the value of the spectrum line's amplitude that is of the highest value. This value is normalized by dividing it by the mean of all lines' amplitudes for the range from $1 \mathrm{~Hz}$ to $20 \mathrm{~Hz}$. Normalization allows comparison of maximum values for different courses. A typical visual result of tremor frequency assessment by the accelerometer is presented in Fig. 1.

Superficial EMG electrodes (EMG 100C BIOPACK System Inc., US) were placed at standard locations on the carpal flexors and extensors. The frequency of tremor and synchronization of contractions in two antagonistic muscle groups, the flexors and extensors of the wrist, were assessed. Tremor registration by accelerometer and EMG lasted 1.5 minutes. Visual assessment of 10 -second EMG recording was performed by two independent raters (A.W. and T.T.). Synchronization of antagonistic muscle contractions was assumed to be a dominant pattern if it accounted for over $80 \%$ of registered contractions.

The severity of tremor was assessed separately for resting, postural and kinetic tremor using the Tremor Severity Scale [14] and additionally, for kinetic tremor, by the Archimedes spiral drawing test rated with a 0 to 9 grading $[15,16]$. The functional ability of the patients was assessed by the Activities of Daily Living Questionnaire (ADL) [17], and their quality of life by the Quality of Life Essential Tremor Questionnaire (QUEST) [18].

The load test (LT) identifying the dominant tremor generator (central or peripheral) was performed on every patient to determine the type of tremor: EPT or ET-like (ET-L). The frequency of postural tremor before and after placement of a $500 \mathrm{~g}$ weight on the wrist of the out- 

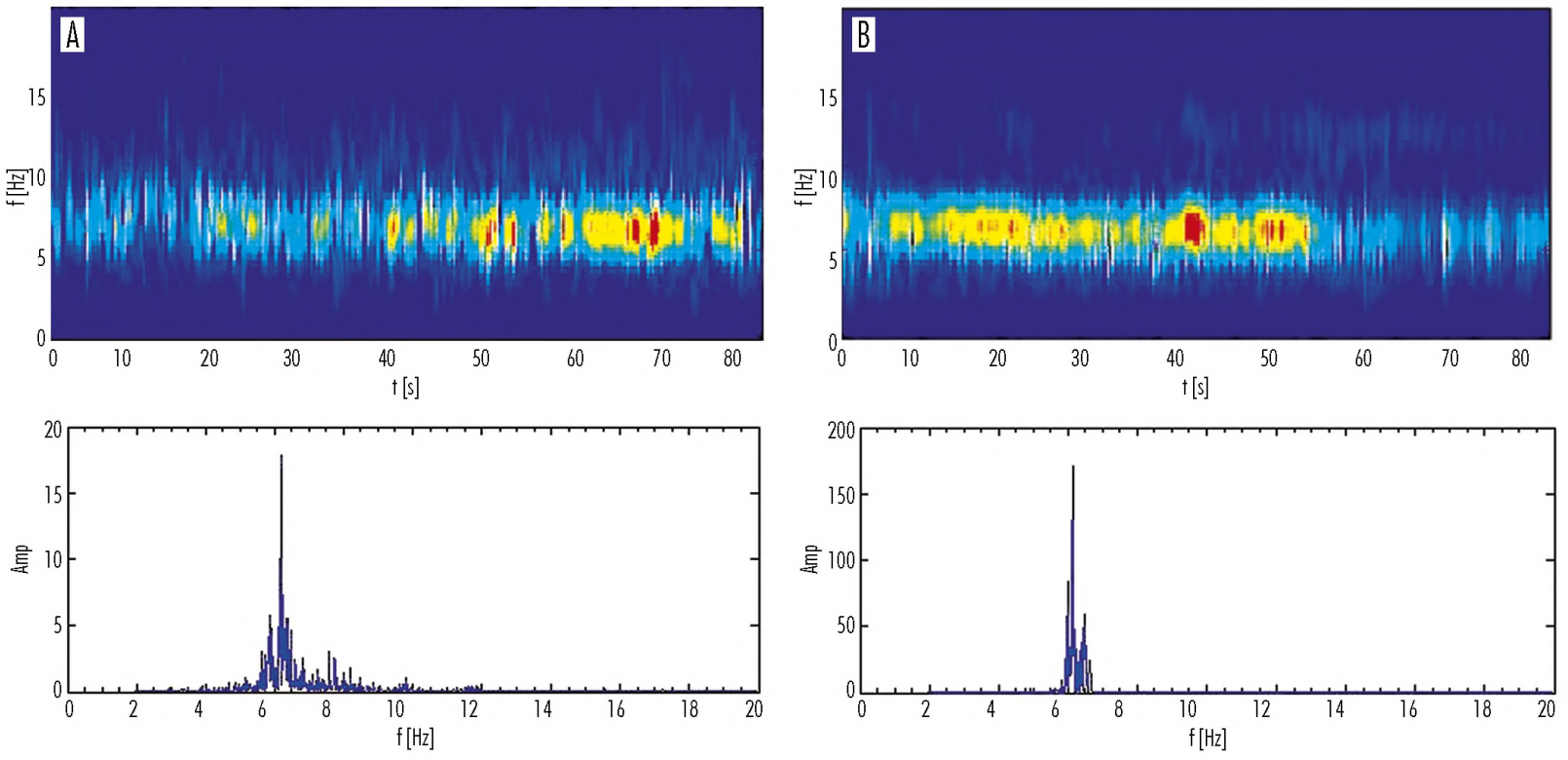

Fig. 1. A) Postural tremor of right hand. B) Postural tremor of left hand

stretched arm of the patient was measured. The criterion for a dominant peripheral tremor generator was a decrease in the tremor frequency greater than $1 \mathrm{~Hz}$ in the LT [15]. The type of ET-L tremor was diagnosed if no de crease in tremor frequency was observed in the LT.

\section{Statistical analysis}

Numerical variables were characterized either by the mean \pm standard deviation (SD) or the median and interquartile range ( $\mathrm{q} 1-\mathrm{q} 3)$, according to their distribution. To assess distribution of variables, the KolmogorovSmirnov test was used. The significance of differences between quantitative data was analysed using the $\chi^{2}$ test, with appropriate Yates modification, as required. The two-tailed Student $t$-test was used to assess differences between normally distributed variables, and the MannWhitney $U$-test was used for other variables. Correlations between variables were assessed using the Spearman rank correlation coefficient $(r s)$ due to the skewed distribution. All analyses were performed with commercial statistical software (STATISTICA for Windows v. 6.0, StatSoft Inc version 8, Poland). A p-value of 0.05 was considered statistically significant.

\section{Results}

Eighty-nine eligible patients ( 38 women and 51 men; mean age: $54.1 \pm 18.4$ years, mean duration of neu-

ropathy: $11.5 \pm 14.0$ years) and 50 controls (including 30 women and 20 men, mean age: $57.2 \pm 11.9$ years) agreed to take part in the study. There were 6 patients with CIDP, 7 patients with PIgM, 35 patients with DP, 11 patients with PA and 30 patients with CMT1. The clinical characteristics of neuropathy in different groups are presented in Table 1.

The presence of upper limb tremor was found in 53 out of $89(59.5 \%)$ patients in the clinical examination and in $66(74 \%)$ patients in the accelerometric assessment, as compared to 6 out of $50(12 \%)$ controls in both clinical and accelerometric assessment $\left(\chi^{2}=42.9, p=0.000\right)$. The onset of tremor in all patients occurred later than onset of neuropathy. At the time of examination, the mean duration of tremor was 5.14 years, as compared to 11.53 years of neuropathy duration.

In controls, only postural tremor was present and in patients with polyneuropathy postural tremor was the most frequent $(70.0 \%)$ type of presenting tremor. Resting tremor was found in $51.2 \%$ of patients, and kinetic tremor in $31.7 \%$ of patients. There were no statistically significant differences between aetiology of polyneuropathy and the presence of resting, postural and kinetic tremor (Table 2).

Average severity of resting, postural and kinetic tremor assessed by the Simple Tremor Severity Scale in all patients with polyneuropathy was $1.1,1.6$ and 1.7 , respectively, which defines a mild tremor. Average kinetic tremor severity assessed through the 9-grade scale of 
Table 1. Characteristics of the study group

\begin{tabular}{|c|c|c|c|c|c|}
\hline \multirow[t]{2}{*}{ Variable } & \multicolumn{5}{|c|}{ Diagnosis } \\
\hline & $\begin{array}{l}\text { CIDP } \\
n=6\end{array}$ & $\begin{array}{c}\text { CMT } \\
n=30\end{array}$ & $\begin{array}{l}P \operatorname{Plg} M \\
n=7\end{array}$ & $\begin{array}{c}\text { Diabetic } \\
\text { polyneuropathy } \\
n=35\end{array}$ & $\begin{array}{c}\text { Alcoholic } \\
\text { polyneuropathy } \\
n=11\end{array}$ \\
\hline Age [years]; mean $\pm \mathrm{SD}$ & $44.7 \pm 19.3$ & $40.2 \pm 15$ & $64.4 \pm 18$ & $64.3 \pm 14.3$ & $58.7 \pm 10.9$ \\
\hline Sex (female/male) & $4 / 2$ & $13 / 17$ & $3 / 4$ & $16 / 19$ & $2 / 9$ \\
\hline $\begin{array}{l}\text { Neuropathy duration } \\
\text { [years]; mean } \pm \mathrm{SD}\end{array}$ & $2.3 \pm 1.0$ & $21.5 \pm 19$ & $3.6 \pm 1.9$ & $8 \pm 7.4$ & $5.09 \pm 2.3$ \\
\hline \multicolumn{6}{|l|}{$\begin{array}{l}\text { Sensory modalities affected } \\
\text { (\% of subjects with): }\end{array}$} \\
\hline interoceptive & 83 & 100 & 100 & 97 & 100 \\
\hline exteroceptive & 50 & 67 & 71 & 66 & 90 \\
\hline \multicolumn{6}{|l|}{$\begin{array}{l}\text { Absent or decreased reflexes } \\
\text { (\% of subjects with): }\end{array}$} \\
\hline triceps & 67 & 56 & 86 & 65 & 73 \\
\hline biceps & 50 & 63 & 71 & 57 & 46 \\
\hline radial & 67 & 70 & 86 & 60 & 73 \\
\hline patellar & 100 & 80 & 57 & 60 & 55 \\
\hline Achilles & 83 & 96 & 100 & 86 & 90 \\
\hline Gait ataxia ( $\%$ of subjects) & 83 & 23 & 43 & 28.5 & 81 \\
\hline \multicolumn{6}{|l|}{$\begin{array}{l}\text { Muscle weakness }(\%) \\
\text { MRC grade }(0-2)\end{array}$} \\
\hline proximal & 33 & 20 & 0 & 20 & 0 \\
\hline distal & 33 & 43 & 0 & 26 & 10 \\
\hline \multicolumn{6}{|l|}{ MRC grade (3-5) } \\
\hline proximal & 67 & 80 & 100 & 80 & 100 \\
\hline distal & 67 & 57 & 100 & 74 & 90 \\
\hline
\end{tabular}

CIDP - chronic inflanmatory demyelinating polyradiculonewropathy, CMTI - Charcot-Marie-Tooth type 1, PIgM- monoclonal IgM polynewropathy, SD - standard deviation, $M R C-$ Medical Research Council

Archimedes spiral drawing in patients with polyneuropathy was 2.1 and in controls $1.8(p=0.0009)$. No differences of tremor severity among patients with different aetiologies of neuropathy were observed. The results of functional ability assessment by ADL were significantly worse for patients with tremor versus patients without tremor $(p=0.000017)$. Patients with CMT1 were more disabled than patients with DP $(12.7$ vs. $7.9, p=0.045)$ or $\mathrm{AP}(12.7$ vs. $3.9, p=0.048)$. Similarly, from the results of the QUEST questionnaire, patients with CMT1 assessed their quality of life as lower in comparison to patients with DP (13.9 vs. 8.51, $p=0.04$ ). Among other groups of patients with polyneuropathy, no statistically significant differences were found.

The frequency of all types of tremor in patients ranged from 1.0 to $18.5 \mathrm{~Hz}$ (mean: $6.6 \mathrm{~Hz}$ ), similarly as in con- trols (mean: $5.8 \mathrm{~Hz}$ ). The amplitude of all types of tremor in patients also ranged widely, from 0.01 to $0.28 \mathrm{~mm}^{2} / \mathrm{s}$. There was no difference in the mean value of amplitude in patients and controls. The average frequency and amplitude of postural tremor in patients with polyneuropathy of different origin are presented in Table 2.

Synchronization of agonistic and antagonistic muscle contraction was the dominant pattern of EMG recording in $80 \%$ of patients with polyneuropathy and tremor (4 patients with CIDP, 20 with CMT1, 21 with DP, 7 with AP). An asynchronous pattern of contraction was recorded only in $6 \%$ of patients ( 2 patients with CMT1 and 2 with AP). A mixed contraction pattern (synchronous in one hand and asynchronous in the second one) was observed in $15 \%$ of the study group (1 patient with CIDP, 2 with CMT1, 6 with DP and 3 with AP). 
Table 2. Comparison of tremor characteristics in patients with neuropathies of different origin

\begin{tabular}{|c|c|c|c|c|c|}
\hline \multirow{2}{*}{$\begin{array}{l}\text { Tremor } \\
\text { characteristics }\end{array}$} & \multicolumn{5}{|c|}{ Diagnosis } \\
\hline & $\begin{array}{l}\text { CIDP } \\
n=6\end{array}$ & $\begin{array}{c}\text { CMT } \\
n=30\end{array}$ & $\begin{array}{l}P \operatorname{Plg} M \\
n=7\end{array}$ & $\begin{array}{c}\text { Diabetic } \\
\text { polyneuropathy } \\
n=35\end{array}$ & $\begin{array}{c}\text { Alcoholic } \\
\text { polyneuropathy } \\
n=11\end{array}$ \\
\hline Tremor in clinical examination & $\begin{array}{c}3 \\
(50.0 \%)\end{array}$ & $\begin{array}{c}23 \\
(76.6 \%)\end{array}$ & 0 & $\begin{array}{c}20 \\
(57.4 \%)\end{array}$ & $\begin{array}{c}6 \\
(54.5 \%)\end{array}$ \\
\hline $\begin{array}{l}\text { Tremor in accelerometric } \\
\text { examination }\end{array}$ & $\begin{array}{c}5 \\
(83.3 \%)\end{array}$ & $\begin{array}{c}22 \\
(73 \%)\end{array}$ & 0 & $\begin{array}{c}29 \\
(83 \%)\end{array}$ & $\begin{array}{c}9 \\
(82 \%)\end{array}$ \\
\hline $\begin{array}{l}\text { Mean frequency of postural } \\
\text { tremor }[\mathrm{Hz}]\end{array}$ & 9.0 & 7.8 & - & 7.7 & 9.7 \\
\hline $\begin{array}{l}\text { Mean amplitude of postural } \\
\text { tremor }\left[\mathrm{mm}^{2} / \mathrm{s}\right]\end{array}$ & 0.23 & 0.01 & - & 0.073 & 0.046 \\
\hline Rest tremor & $\begin{array}{c}3 \\
(50.0 \%)\end{array}$ & $\begin{array}{c}16 \\
(53.3 \%)\end{array}$ & 0 & $\begin{array}{c}19 \\
(54.3 \%)\end{array}$ & $\begin{array}{c}4 \\
(36.0 \%)\end{array}$ \\
\hline Postural tremor & $\begin{array}{c}5 \\
(83.3 \%)\end{array}$ & $\begin{array}{c}19 \\
(63.3 \%)\end{array}$ & 0 & $\begin{array}{c}27 \\
(77.1 \%)\end{array}$ & $\begin{array}{c}7 \\
(63.6 \%)\end{array}$ \\
\hline Action tremor & $\begin{array}{c}2 \\
(33.3 \%)\end{array}$ & $\begin{array}{c}12 \\
(40 \%)\end{array}$ & 0 & $\begin{array}{c}11 \\
(31.4 \%)\end{array}$ & $\begin{array}{c}1 \\
(9.0 \%)\end{array}$ \\
\hline $\begin{array}{l}\text { ET-like tremor } \\
\text { (tremor/ number } \\
\text { of examined limbs) }\end{array}$ & $\begin{array}{c}4 / 12 \\
(33.3 \%)\end{array}$ & $\begin{array}{l}23 / 60 \\
(38.3 \%)\end{array}$ & 0 & $\begin{array}{l}25 / 70 \\
(35.7 \%)\end{array}$ & $\begin{array}{c}10 / 22 \\
(45.4 \%)\end{array}$ \\
\hline $\begin{array}{l}\text { Enhanced physiological } \\
\text { tremor (tremor/ number } \\
\text { of examined limbs) }\end{array}$ & $\begin{array}{c}4 / 12 \\
(33.3 \%)\end{array}$ & $\begin{array}{l}24 / 60 \\
(40 \%)\end{array}$ & 0 & $\begin{array}{c}16 / 70 \\
(22.9 \%)\end{array}$ & $\begin{array}{l}2 / 22 \\
(9.1 \%)\end{array}$ \\
\hline
\end{tabular}

CIDP - chronic inflammatory demyelinating polyradiculoneuropathy, CMTI-Charot-Marie-Tooth type 1, PIgM-monoclonal IgM polynewropathy, ET - essential tremor

Table 3. Comparison of mean values of distal motor latency (DML) and mean amplitude of compound muscle action potential (CMAP) of right median and ulnar nerve examination in different types of tremor

\begin{tabular}{|c|c|c|c|c|c|c|c|c|}
\hline \multirow[t]{3}{*}{ Types of tremor } & \multicolumn{4}{|c|}{ Median nerve } & \multicolumn{4}{|c|}{ Ulnar nerve } \\
\hline & \multicolumn{2}{|c|}{$\begin{array}{l}\text { DML } \\
{[\mathrm{ms}]}\end{array}$} & \multicolumn{2}{|c|}{$\begin{array}{l}\text { CMAP amplitude } \\
{[\mathrm{mV}]}\end{array}$} & \multicolumn{2}{|c|}{$\begin{array}{l}\mathrm{DML} \\
{[\mathrm{ms}]}\end{array}$} & \multicolumn{2}{|c|}{$\begin{array}{l}\text { CMAP amplitude } \\
{[\mathrm{mV}]}\end{array}$} \\
\hline & $\begin{array}{l}\text { Tremor } \\
\text { present }\end{array}$ & $\begin{array}{l}\text { Tremor } \\
\text { absent }\end{array}$ & $\begin{array}{l}\text { Tremor } \\
\text { present }\end{array}$ & $\begin{array}{l}\text { Tremor } \\
\text { absent }\end{array}$ & $\begin{array}{l}\text { Tremor } \\
\text { present }\end{array}$ & $\begin{array}{l}\text { Tremor } \\
\text { absent }\end{array}$ & $\begin{array}{l}\text { Tremor } \\
\text { present }\end{array}$ & $\begin{array}{l}\text { Tremor } \\
\text { absent }\end{array}$ \\
\hline Rest tremor & 6.60 & 13.98 & 5.95 & 4.30 & 2.60 & 5.86 & 3.41 & 3.31 \\
\hline Postural tremor & 6.12 & 5.14 & 5.41 & 4.98 & 3.69 & 5.56 & 4.29 & 3.45 \\
\hline Action tremor & 5.91 & 5.48 & 5.69 & 5.17 & 4.77 & 3.83 & 5.06 & 3.62 \\
\hline Essential tremor-like tremor & 12.49 & 10.45 & 5.06 & 5.57 & 4.56 & 3.71 & 3.48 & 4.73 \\
\hline Enhanced physiological tremor & 11.41 & 10.82 & 4.15 & 5.87 & 3.32 & 4.55 & 3.92 & 3.94 \\
\hline
\end{tabular}

Within the whole group of patients, tremor of ET-L type was more frequent - confirmed in $62(38 \%)$ limbs - than EPT, which was present in 46 (28\%) limbs $\left(\chi^{2}=7.95, p=0.0048\right)$. This difference was even greater for patients with AP (45.4\% vs. $9.1 \%)$ and DP $(35.7 \%$ vs. $22.0 \%)$. In patients with CIDP and CMT1, the ET-L tremor type and EPT were present in an equal percentage of cases (Table 2).
Patients with neuropathy and accompanying tremor, compared to patients without tremor, did not have significantly different results in nerve conduction velocity for the medial nerve $(45.2 \mathrm{~m} / \mathrm{s}$ vs. $48.5 \mathrm{~m} / \mathrm{s})$ and ulnar nerve $(46.1 \mathrm{~m} / \mathrm{s}$ vs. $45.5 \mathrm{~m} / \mathrm{s})$. The results of sensory and motor conduction studies did not differ in patients with resting, postural and kinetic tremor, as well as in patients with ET-L or EPT type of tremor. No correlation bet- 
ween the presence and type of tremor, and the type of neuropathy (axonal, demyelinating or mixed) was found. The mean distal motor latency (DML) and the mean amplitude of the compound muscle action potential (CMAP) of patients with different types of tremor are shown in Table 3.

\section{Discussion}

The study shows the common occurrence of upper limb tremor in patients with peripheral neuropathy, much more often than in the control group. This is the first study to assess prevalence and types of tremor in polyneuropathy of different origin compared with a control group. The results are consistent with the few papers on this topic published so far, mostly on patients with hereditary polyneuropathy. Yudell et al. [11] described 4 patients with Roussy-Levy syndrome, in whom he observed not only typical, postural and kinetic upper limb tremor, but also tremor of the face, vocal tremor, and tremor of the lower limbs and trunk. Ryan and Jones described the case of a 13-year-old boy who had been diagnosed with inflammatory polyneuropathy, in which the first dominant clinical symptom was irregular kinetic tremor of upper limbs [19]. Salisachs et al. $[10]$ also described vocal tremor in one patient, lower limb tremor in 3 patients, and postural and kinetic upper limb tremor in all 7 patients, one of whom had resting tremor. They did not, however, observe tremor of the face and trunk [20]. Thomas et al. analysed symptoms in 61 patients with CMT1 and found enhanced postural upper limb tremor only in 8 patients accompanied by ataxia and diagnosed as Roussy-Levy syndrome.

In the literature, there are also descriptions of common occurrence of tremor in patients with CIDP. In the study performed by Dalakas et al., tremor was present during the first attack of the disease in 2 out of 7 patients, and during the second or third relapse it was present in most examined patients. According to the authors, tremor was the onset symptom of a successive disease stage and it reflected the degree of polyneuropathy intensity [3]. Busby et al. [1,2] in their study, which characterized different types of polyneuropathy in the course of immunological disorders, stated that in subacute and chronic sensory-motor polyneuropathy, enhanced kinetic tremor occurred in only 4 out of 102 patients.

Data regarding common prevalence of tremor in polyneuropathy with paraproteinaemia IgM were not confirmed by this study. Until now, published data con- cerning PIgM have been based on case reports, or on several papers analysing tremor in rather small groups (6-18) of patients, and the recently published report of Ahlskog et al. [21] based on a cohort of 207 cases of IgM neuropathy. Bain et al. [9] described symmetrical and irregular tremor of both distal and proximal parts of limbs in all 6 patients with PIgM. Smith et al. [22] observed tremor of upper limbs in 16 out of 18 patients with PIgM. Seven of them presented tremor similar to parkinsonian tremor, and in 5 patients additional kinetic lower limb tremor occurred. In a medical record database of 207 patients of IgM monoclonal gammopathy of undetermined significance (IgM-MGUS) Ahlskog et al. [21] found tremor in $60(29 \%)$ cases, significantly higher than in 414 patients of other cause neuropathy (9\%) serving as a control group. In 25 of 60 patients with tremor, an alternative potential tremor mechanism (parkinsonism, ET, drugs, etc.) was also found.

The variation of tremor prevalence in studies presented above (almost all vs. 29\%) is difficult to explain. Our study is based on a small number of cases ( 7 only) and could not be representative for the PIgM patient population. We also excluded patients with parkinsonism and other diseases and states known to cause tremor. If we take into account only 35 of 207 (16.9\%) tremor cases without an alternative mechanism, the results of the study of Ahlskog et al. are much closer to our study than to the studies of Bain et al. [9] or Smiths et al. [22].

Our study showed that tremor accompanying polyneuropathy is mainly postural, but in many cases the accompanying occurrence of kinetic and/or resting tremor was also observed. Isolated rest tremor was observed least often. Postural tremor usually occurs in CIDP, whereas resting and kinetic tremor are common in all types of polyneuropathy with the exception of alcoholic polyneuropathy. Similarly, the prevalence of postural and kinetic tremor is most often described in previous literature $[9,13,22]$. Monaco and Turri, who characterized inflammatory polyneuropathy, stated that postural tremor is an inherent symptom of polyneuropathy CIDP [13]. It seems to confirm the result of our study, which shows the highest prevalence of postural tremor in CIDP as compared to other groups who were examined.

So far, only a few studies have been published that concern characteristics of tremor accompanying polyneuropathy in terms of full assessment of the tremor parameters such as frequency and amplitude. Salisachs et al. [10] described postural and kinetic tremor of upper limbs in all 7 patients, one of whom presented a resting tremor of $4 \mathrm{~Hz}$ frequency. Bain et al. [9] described a group of 
6 patients with tremor of both distal and proximal parts of limbs, including arm muscles, and concluded that tremor frequency in distal muscles was lower $(2.5-5.5 \mathrm{~Hz})$ than in proximal muscles $(3.7-5.5 \mathrm{~Hz})$. In the study of Dalakas, Teravainen and Engel [3] the recorded tremor varied in frequency between 3.3 and $6.4 \mathrm{~Hz}$. Reviewing the pathophysiology of non-parkinsonian tremor, Deuschl and Bergman [23] stated that the frequency of neuropathic tremor in arm and hand muscles is between 3 and $6 \mathrm{~Hz}$, but cited only a few supportive data. Tremor frequency between 3 and $6 \mathrm{~Hz}$ was registered in about $50 \%$ of our patients, while in many others much higher tremor frequencies were observed, and in some others lower. Our results question the generally accepted opinion of low frequency of tremor in neuropathy. We do not have an explanation for our results, but we think that the mechanism of tremor in some neuropathic patients may be different than in others and this difference could explain the variety in tremor frequencies. There are no clear experimental data supporting the view of a peripheral mechanism of neuropathic tremor. More detailed clinical studies are also needed to prove the opinion on the tremor frequency range in neuropathic patients.

We revealed no dependence of tremor occurrence on lowered velocity of conduction or other parameters of electrophysiological assessment in a patient group. Similarly, we did not observe dependence of tremor occurrence on the dominant form of axonal or demyelination lesion. A few studies by other authors concerning the relation between lowered velocity of conduction and tremor occurrence also did not explicitly reveal such dependence. Busby $e t a l$. proved that improvement of conduction velocity in peripheral nerves due to treatment of $\mathrm{PIgM}$ caused an increase of frequency in the observed tremor. Additionally, they stated that conduction improvement, due to treatment with immunoglobulin, steroids and other immunosuppressants, was connected with a decrease in tremor intensity. This observation lets us assume that a change of nerve conduction velocity may affect tremor parameters. The same authors showed that tremor frequency increases in proximal parts of limbs, but this is not linearly dependent on lowering conduction velocity in a given section of the examined nerve. No correlation between tremor frequency and intensity of other polyneuropathy symptoms, such as paresis or sensory disorders, have been mentioned in the available literature $[3,24]$. Nor is there any information about changes of conduction parameters or dependence on a specific type of tremor. Thus, the present study is the only one which, based on analysis of the results obtained, can prove that tremor is not a symptom dependent on conduction parameters.
According to our results, ET-like type of tremor in polyneuropathy occurs more often (38\%) than EPT (28\%). This suggests that the central generator of tremor could dominate even when the peripheral nervous system is damaged. The location of the tremor generator in polyneuropathy is still unknown, but there are many data supporting the central mechanism of tremor in polyneuropathy. According to Dalakas et al., tremor in the examined patients with dysgammaglobulinaemic polyneuropathy resembles recurrent pronation-supination movement typical for resting tremor in Parkinson disease patients, and indicates the central aetiology of tremor. Bain et al. [9] suggested that patients with IgM polyneuropathy have a specific cerebellar functional disturbance caused by the delayed and distorted afferent input. Recently, Weiss et al. [25] provided direct evidence for a central oscillator underlying neuropathic tremor in one patient with IgM polyneuropathy and tremor effectively treated with bilateral deep brain stimulation of the ventral intermediate nucleus of the thalamus. The study supports the concept of defective afferent input resulting in dysregulation of the cerebellar-thalamocortical motor network in neuropathic tremor.

It should be stated that the very high incidence of tremor in our neuropathic patients could be related to the method of patient recruitment. We are a tertiary re ferral centre for movement disorders and patients with unusual manifestations of movement disorders are more likely to be referred to our centre. However, the patients for the study were recruited from the cohort of patients for whom we are a regional referral centre. We diagnosed them and followed them for long-term treatment. For that reason we believe the bias of the study does not significantly influence our results, but the next study should be done on a different population.

\section{Disclosure}

The study was approved by the Jagiellonian University Medical College Bio-Ethical Committee. This work has been supported by the grant of the Polish Ministry of Science no. K/PBP/000038.

Authors report no conflict of interest.

\section{References}

1. Busby M., Nithi K., Mills K., et al. The tremor associated with non-paraproteinaemic acquired demyelinating polyneuropathy - a case study. $J$ Neurol 2003; $250: 486-487$.

2. Busby M., Donaghy M. Chronic dysimmune neuropathy. $J$ Neurol 2003; 250: 714-724.

3. Dalakas M.C., Teräväinen H., Engel W.K. Tremor as a feature of chronic relapsing and dysgammaglobulinemic polyneu- 
ropathies. Incidence and management. Arch Nourol 1984; 41 : 711-714.

4. Smith I.S. The natural history of chronic demyelinating neuropathy associated with benign $\mathrm{IgM}$ paraproteinaemia. A clinical and neurophysiological study. Brain 1994; 117: 949957.

5. Smith I.S. Tremor in peripheral neuropathy. In: Findley L.J., Koller W.C. [eds.]. Handbook of Tremor Disorders. Marcel Dekker, Nero York 1995, pp. 443-454.

6. Harding A.E., Thomas P.K. The clinical features of hereditary motor and sensory neuropathy types I and II. Brain 1980;103: 259-280.

7. Saverino A., Solaro C., Capello E., et al. Tremor associated with benign IgM paraproteinaemic neuropathy successfully treated with gabapentin. Mov Disord 2001; 16: 960-974.

8. Tankisi H., Pugdahl X., Fuglsang-Frederkisen A. Pathophysiology inferred from electrodiagnostic nerve test and classification of polyneuropathies. Suggested guidelines. Clin Neurophysiol 2005; 116: 1571-1580.

9. Bain P.G., Britton T.C., Jenkins I., et al. Tremor associated with benign IgM paraproteinemic neuropathy. Brain 1996; 119: 789-799.

10. Salisachs P. Charcot-Marie-Tooth disease associated with essential tremor: report of 7 cases and a review of the literature. $J$ Neurol Sci 1976; 28: 17-40.

11. Yudell A., Dyck P.J., Lambert E.H. A kinship with the RoussyLevy syndrome. Arch Neurol 1965; 13: 432-440.

12. Ghosh A., Young A. Early tremor seen in IgG-paraproteinaemic neuropathy. $J$ Neurol 2001; 248: 225-226.

13. Monaco S., Turri E., Zanusso G., et al. Treatment inflammatory and paraproteinaemic neuropathies. Curr Drug Targets Immune Endocr Metabol Disord 2004; 4: 141-148.

14. Cerosimo M.G., Koller W.C. [eds.]. Essential tremor. In: Movement disorders: neurologic principles and practice. $2^{\text {nd }} \mathrm{ed}$. McGraw-Hill Companies Inc., New York 2004, pp. 431-458.

15. Bain P.G., Findley L.J., Atchison P, et al. Assessing tremor severity. J Neurol Neurosurg Psychiatry 1993; 56: 868-873.

16. Liu X., Carrol C.B., Wang S.Y., et al. Quantifying drug-induced dyskinesias in the arms using digitised spiral-drawing tasks. J Neurosci Methods 2005; 144: 47-52.

17. Jankovic J., Fahn S. Physiologic and pathologic tremors: diagnosis, mechanism and management. Ann Intern Med 1980; 93: 460-465.

18. Tröster A., Pahwa R., Fields J.A., et al. Quality of life in Essential Tremor Questionnaire (QUEST): development and initial validation. Parkinsonism Relat Disord 2005; 11: 367-373.

19. Ryan M.M., Johnes H.R. Jr. CMTX mimicking childhood chronic inflammatory demyelinating neuropathy with tremor. Muscle Nerve 2005; 21: 528-530.

20. Dyck PJ., Lais A.C., Ohta M., et al. Chronic inflammatory polyradiculoneuropathy. Mayo Clin Proc 1975; 50: 621-637.

21. Ahlskog M., Kumar N., Mauermann M., et al. IgM-monoclonal gammopathy neuropathy and tremor: a first epidemiologic case control study. Parkinsomism Relat Disord 2012: 18: 748 752.

22. Smith I.S. Tremor associated with peripheral neuropathy. Elecroencephalogr Clin Neurophysiol 1989; 72: 403-409.

23. Deuschl G., Bergman H. Pathophysiology of nonparkinsonian tremors. Mov Disord 2002; 12: S41-S48.
24. Bosch E.P., Smith B.E. Disorders of peripheral nerves. In: Bradley W.G., Daroff R.B., Fenichel G.M., Jankovic J. [eds.]. Neurology in Clinical Practice. Elserver, Philadelphia 2004; pp. 299-2401.

25. Weiss D., Govindan B. Central oscillators in patient with neuropathic tremor: evidence from intraoperative local field potential recordings. Mov Disord 2011; 26: 322-327. 